\title{
Socio-ecological practices of constructing comfortable and safe urban environment
}

\author{
Dmitry Lushnikov ${ }^{1}$, Valentine Ivashova ${ }^{2,},{ }^{*}$ Natalia Popova $^{1}$, Victoria Gladchenko ${ }^{3}$, and \\ Bella Taysaeva ${ }^{4}$ \\ ${ }^{1}$ North Caucasus Federal University, 1, Pushkin Street, Stavropol, 355017, Russia \\ ${ }^{2}$ Stavropol State Agrarian University, 12, Zootekhnichesky Lane, Stavropol, 355017, Russia \\ ${ }^{3}$ Armavir State Pedagogical University, 159, R. Luxemburg Street, Armavir, 352901, Russia \\ ${ }^{4}$ North Ossetian State University, 44-46, Vatutina Str., Vladikavkaz, 362025, Russia
}

\begin{abstract}
The article presents the socio-ecological practices of constructing a comfortable and safe urban environment on the example of the southern region of Russia and current trends in the scientific discussion affecting this topic. We considered expert assessments of the quality of training graduates of gardening and landscape construction programs based on the requirements of the Federal State Educational Standard. We presented the role of agrarian education in the promotion of environmentally friendly technologies in the preparation of graduates of gardening and landscape construction. Attention is paid to the modern skills of designing the urban environment based on the practice of involving the local community in this process and promoting transdisciplinary methods of researching the needs of the population. We proposed the areas of improving the process of training students under the program of garden and park and landscape construction, capable of contributing to the achievement of the strategic national goal of developing a comfortable and safe environment for the life of Russians.
\end{abstract}

\section{Introduction}

In the national goals of the Russian Federation for the period up to 2030, one goal is of developing a comfortable and safe environment for life. At the state level it is shown the importance of factors for ensuring a comfortable and safe environment of settlements, which is formed not only due to material investments in its development, but also positive social and environmental practices of the population, moving to the level of everyday life.

Socio-ecological practices of constructing a comfortable and safe urban environment are presented in the research tracks of the world scientific community and are an interdisciplinary object of study of social, engineering, agricultural and biological sciences.

The authors of the article M.A. Benoliel, M. Manso, P.D. Ferreira, C.M. Silva, and C.O. Cruz are considering the issues of greening in the city's transport infrastructure systems and their potentially positive impact on achieving sustainable development goals [1].

* Corresponding author: vivashov@mail.ru 
Environmental, economic, and social benefits are achieved through the integration of green spaces into the urban environment. The researchers studied the attitude of the townspeople to the greening of the transport infrastructure: against the background of positive assessments it is evident the low willingness of the townspeople to pay for additional "green" comfort. Increased seats and secure, comfortable waiting areas are preferred.

An important aspect of the implementation of social and environmental practices in an urban environment is considered by the authors of the article O. Pilipenko, E. Skobeleva, A. Bulgakov [2]. The authors have developed a methodology for quantitatively assessing the availability, comfort, and environmental safety of residential urban areas. It was concluded that it is necessary to comply with pedestrian communications, open urban spaces for recreation, games, and sports with the requirements of environmental safety. In addressing issues of urban environment development, city authorities should provide for social and environmental practices that educate normative boundaries through the improvement and comfort of zoned territorial locations.

Authors N. Danilina, D. Vlasov, I. Teplova draw attention to the fact that, against the background of global challenges of urban development, it is necessary to develop new approaches to the design of the urban environment. The streets of the city become the centre of people's life and a place where many social functions are concentrated [3]. In this regard, the authors propose a model of urban zoning based on the needs of the population. For our study, it is important to involve the population in the socio-ecological practices of constructing the urban environment. This is the activity that ensures the participation of city residents in the development of targeted programs to improve the comfort and safety of the urban environment.

The issue of the accessibility of the urban environment for persons with disabilities is being actively considered. In their article the authors C.E. Mediastika, A.S. Sudarsono, L. Kristanto offer an interesting approach to segmenting the uniqueness and recognisability of city places by sound design [4]. This approach does not worsen the situation of ordinary people without restrictions, but significantly improves the situation for visually impaired people. The authors conducted a series of studies to characterize the soundscape of the city's public spaces. Sound metering will provide guidance, safety and a comfortable acoustic environment for people with disabilities.

The work of the city infrastructure is being rebuilt, new digital and engineering solutions are being introduced, which are designed to provide a comfortable and safe living environment for citizens. The authors of the study "Smart Cities" as a Modern Model of Sustainable Development of Territories" bring up for discussion the issue of spatial heterogeneity of their distribution on the territory of Russia [5]. The rating assessment and the selection of the top 10 best cities allow us to show positive practices and guidelines for the strategic development of the urban environment of Russian cities.

An important aspect of the development of the urban environment is to ensure the comfort and safety of pedestrians on the sidewalks. Study authors N. Chintawar, T. Tallam, K.M. LakshmanaRao propose a model for analyzing the parameters of pedestrian flow (speed, density, intensity) and the design of sidewalks in connection with these indicators [6]. The model for predicting the pedestrian flow makes it possible to design the socioecological conditions for the development of the urban environment, taking into account the segmentation of the pedestrian load [7]. The priority of the practices of local territorial mobility of citizens in the target settings for the development of a comfortable and safe environment remains important.

With the development of technologies in the urban environment, new challenges arise, to which it is important to respond to municipalities in terms of ensuring the safety and tranquillity of residents, taking into account their views on the ongoing changes. The authors of the publication C. Grossi, L. Martin, C. Wolter offer their experience of 
attracting public opinion in assessing the risks of such innovations as unmanned transport in an urban environment [8]. To develop the relevant competencies of specialists whose professional activities are related to the construction of a comfortable and safe environment, a conclusion is made on the practices of involving the local community in the assessment of technological innovations. Accordingly, seemingly non-core skills in researching the opinions of stakeholders and communicative competencies with different categories of potential consumers - their segmentation and study of requests - become necessary. It is important to note that in the process of studying requests, it is possible to promote ideas of positive socio-ecological practices through research tools.

Providing a comfortable and safe environment is impossible without the use of environmentally friendly building materials that meet the standards for the construction of urban facilities. The authors of the study L.V. Zakrevskaya, P.A. Lubin, I.A. Gandelsman, K.A. Andreeva offer an original way to strengthen architectural structures without disturbing the ecological balance of urban natural landscapes [9]. Thus, all participants in the design processes of urban environment objects and their implementation at all stages should be focused on priority goal - the creation of a favourable socio-ecological landscape. This goal-setting is laid in the period of preparation for professional activity and is no less significant than the technical and technological knowledge of specialists.

The topical issue of climate change on the agenda of social and environmental practices initiates innovative developments in the field of protecting people from unfavourable climatic conditions. The research experience of building overheating control was proposed by the authors A. Badura, I. Martinac, B. Mueller [10]. The design of premises with a microclimate favourable for health and productive work shows an important priority of the social and ecological well-being of people in the goal-setting of the professional activities of construction specialists $[11,12,13]$.

Thus, a brief overview of the directions of scientific discussion, touching upon the issues of social and environmental practices in the design of a safe and comfortable urban environment, shows a number of important areas:

1. Transport, including pedestrian communications of the city should be maximally focused on building green spaces that provide social and environmental benefits to citizens;

2. Urban zoning of territories is gaining great importance in connection with the development of local territorial mobility of citizens within the framework of individual residential complexes, segmentation of pedestrian traffic and the use of modern approaches to solving zoning issues for persons with disabilities [14];

3. Providing a comfortable and safe environment based on the use of environmentally friendly building materials that meet the standards for the construction of urban facilities [15];

4. The introduction of technological solutions in the urban environment requires ensuring the safety and tranquillity of residents, taking into account their opinion about the changes taking place and active information from the municipalities.

\section{Materials and methods}

The empirical part of the study of socio-ecological practices was carried out in the Stavropol Territory in February 2021. Expert information was collected using an electronic questionnaire (Google Forms). In total, 27 people from among specialists from organizations related to landscape construction and gardening in the region took part in it. Organizations are represented by the territories of the regional centre, industrial cities of the Stavropol Territory, cities - centres of municipal districts with a small population and resort cities of the Caucasian Mineral Waters group. Expert survey data was processed in SPSS 
Statistics (version 21) and presented in a generalized form of statistical distributions. The research toolkit included 20 questions, which are structured in sections: assessment of the competence of graduates of higher education program "Garden, Park and Landscape Construction" in accordance with the requirements of the Federal State Educational Standard; characteristics of the problem field in regional practices of designing a comfortable and safe urban environment; the practice of involving the local community in the development of targeted programs for the improvement of settlements in the South of Russia. The information blocks of the expert survey questionnaire made it possible to concretize the areas of improving social and environmental regional practices to achieve the strategic national goal: the development of a comfortable and safe environment for the life of Russians.

\section{Results and discussion}

The ranking by the expert community of the competencies presented in the current Federal State Educational Standard of the educational program "Garden, Park and Landscape Construction", according to the degree of importance, shows that the first 3 places are occupied by the following competences: 1st place - the ability to design objects of landscape architecture in order to form a comfortable urban environment (noted by $100 \%$ of survey participants); 2nd place - possession of the main methods and means of graphical presentation of project documentation and fine arts skills; the ability to conduct landscape analysis, assess the state of plants at the stage of pre-design research; the ability to apply a creative approach in the design and design of landscape architecture objects, taking into account modern trends (noted by $71.4 \%$ of survey participants); 3rd place - the ability to solve standard tasks of professional activity based on information and bibliographic culture using information and communication technologies and taking into account the basic requirements of information security; readiness to implement technologies for growing planting material: ornamental trees and shrubs, flower crops, lawns in open and protected ground; the ability to apply modern research methods in the field of landscape architecture; readiness to perform calculations and design of parts and assemblies in accordance with the terms of reference (noted by $57.1 \%$ of survey participants).

The expert community assessed the competencies from the Federal State Educational Standard according to the degree of formation among graduates of the educational program "Garden, Park and Landscape Construction", which shows that the following competencies remain less formed. The data is presented in Table 1.

Table 1. Less developed competencies of graduates of the educational program "Garden, Park and Landscape Construction".

\begin{tabular}{|c|c|c|}
\hline $\begin{array}{c}\text { Unformed } \\
\text { level }\end{array}$ & Content characteristic & $\begin{array}{c}\text { \% of experts who } \\
\text { noted unformedness }\end{array}$ \\
\hline \multirow{2}{*}{1} & $\begin{array}{c}\text { - readiness to appoint and carry out activities for the } \\
\text { maintenance of objects of landscape architecture; } \\
- \text { willingness to conduct an experiment according to a } \\
\text { given method, to analyze the results; } \\
\text { - readiness to participate in the preparation of design } \\
\text { and estimate documentation, to determine the cost } \\
\text { parameters of the main production resources during } \\
\text { design and construction; }\end{array}$ & $\begin{array}{c} \\
\text { noted by } 40.7 \% \text { of } \\
\text { survey participants }\end{array}$ \\
\hline 2 & $\begin{array}{c}\text { - understanding the role of the main components of } \\
\text { urban ecosystems in the formation of objects of } \\
\text { landscape architecture in various climatic, } \\
\text { geographical conditions, taking into account the }\end{array}$ & $\begin{array}{c}\text { noted by } 37.1 \% \text { of } \\
\text { survey participants }\end{array}$ \\
\hline
\end{tabular}




\begin{tabular}{|c|c|c|}
\hline & technogenic load; & \\
\hline 3 & $\begin{array}{l}\text { - readiness to perform calculations and design of parts } \\
\text { and assemblies in accordance with the terms of } \\
\text { reference; } \\
\text { - understanding of engineering and technological } \\
\text { issues and design solutions associated with the design } \\
\text { of landscape architecture objects }\end{array}$ & $\begin{array}{l}\text { noted by } 29.6 \% \text { of } \\
\text { survey participants }\end{array}$ \\
\hline
\end{tabular}

Thus, the socio-ecological competence of graduates through understanding the role of the main components of urban ecosystems, taking into account the technogenic load, takes an important place in the qualitative assessment of the level of their readiness for labour processes.

In addition, referring to the theoretical conclusions of the scientific discussion of socioecological practices in the design of a safe and comfortable urban environment, we see insufficient attention to the social and research competencies of graduates. Specialists are required to have modern skills in designing an urban environment based on the practice of involving the local community in this process and promoting transdisciplinary methods for researching the needs of the population $[16,17]$.

Among the difficulties faced by specialists - graduates of previous years, they name the lack of practical skills (noted by $29.6 \%$ of the survey participants), lack of additional knowledge (noted by $29.6 \%$ of the survey participants); it was difficult to get used to the routine, working conditions, and workloads (noted by $14.8 \%$ of the survey participants). The remaining $26.0 \%$ of the survey participants did not experience difficulties.

In the course of the survey, the experts explained that the allowances and surcharges they receive at work are related to the payment of overtime work, work on weekends and holidays (noted by $57.1 \%$ of the survey participants), as well as with the results of the enterprise as a whole and a separate subdivision (noted by $42.9 \%$ of the survey participants). In addition, one in six of the surveyed experts said that special achievements and rationalization proposals are encouraged in their work. Thus, among the competencies of graduates, the most important for successful work in production are: understanding of the production need for overtime work, weekends, holidays and the focus of the employee's activities on the final result.

The ranking of the qualities that, in the opinion of the survey participants, are necessary for the successful performance of labour functions, showed that such qualities as communication skills, the ability to communicate, creative qualities, the ability to solve non-standard tasks are in the first place (57.1\% of survey participants noted respectively); accuracy, diligence (noted by $42.9 \%$ of survey participants). Somewhat less important qualities for successful work, according to experts, are the ability for analytical work, perseverance, patience, the ability to learn, the ability to concentrate, the ability to independently set a problem, the ability to make decisions, leadership qualities, and the ability to lead others.

The competitive situation in the regional labour market among specialists in the field of landscape architecture is quite tense. According to $28.6 \%$ of experts, it is easy to find work according to the educational program in the Stavropol Territory. The remaining $71.4 \%$ of experts say that you can find a job if you try very hard.

The professional community of specialists working in the field of landscape architecture is characterized by a high degree of interest in professional activities and is aimed at developing both special professional competencies and the qualities of a leader. Accordingly, the competitive environment for graduates of the direction of training "Garden, Park and Landscape Construction" requires a high level of professional training. 


\section{Conclusion}

The conducted theoretical analysis of the scientific discussion in the subject area under consideration, the empirical results of the study of the opinions of the expert community, allow us to draw a number of conclusions.

1. Among modern social and environmental practices in ensuring a safe and comfortable urban environment, emphasis is placed on building in green spaces that provide social and environmental benefits to citizens; the use of environmentally friendly building materials; urban zoning of territories in connection with the development of local territorial mobility of citizens within the framework of individual residential complexes; development of feedback with residents to promptly inform municipalities about emerging issues $[18,19]$.

2. In the preparation of graduates of the programs of higher education "Garden, Park and Landscape Construction" an important place is given to the design of objects of landscape architecture in order to form a comfortable urban environment. The socioecological competence of graduates is achieved through understanding the role of the main components of urban ecosystems, taking into account the technogenic load; it takes an important place in the qualitative assessment of the level of their readiness for labour processes.

3. Turning to the theoretical conclusions of the scientific discussion of socio-ecological practices in the design of a safe and comfortable urban environment, we see insufficient attention to the social and research competencies of graduates. Specialists are required to have modern skills in designing an urban environment based on the practice of involving the local community in this process and promoting transdisciplinary methods for researching population needs [20].

\section{References}

1. M.A. Benoliel, M. Manso, P.D. Ferreira, C.M. Silva, C.O. Cruz, Building and Environment 195, 107759 (2021)

2. O. Pilipenko, E. Skobeleva, A. Bulgakov, IOP Conference Series: Earth and Environmental Science 666(2), 022054 (2021)

3. N. Danilina, D. Vlasov, I. Teplova, IOP Conference Series: Materials Science and Engineering, 1030(1), 012059 (2021)

4. C.E. Mediastika, A.S. Sudarsono, L. Kristanto, Advances in Science, Technology and Innovation, 97-107 (2021)

5. N.Yu. Sorokina, L.N. Chaynikova, I.V. Sharova, Lecture Notes in Networks and Systems 155, 1185-1194 (2021)

6. N. Chintawar, T. Tallam, K.M. LakshmanaRao, Lecture Notes in Civil Engineering 83, 427-437 (2021)

7. L.M. Raswol, IOP Conference Series: Materials Science and Engineering 978(1), 012001 (2020)

8. C. Grossi, L. Martin, C. Wolter, Advances in Intelligent Systems and Computing 1210 AISC, 49-55 (2021)

9. L.V. Zakrevskaya, P.A. Lubin, I.A. Gandelsman, K.A. Andreeva, IOP Conference Series: Materials Science and Engineering 972(1), 012051 (2020)

10. A. Badura, I. Martinac, B. Mueller, IOP Conference Series: Earth and Environmental Science 588(5), 052016 (2020) 
11. V.A. Ivashova, V.A. Burlyaeva, I.V. Yushchenko et al., E3S Web of Conferences 224, 04039 (2020)

12. V.Y. Spiridonov, S.G. Shabiev, IOP Conference Series: Materials Science and Engineering 962(3), 032035 (2020)

13. J. Leng, Q. Wang, K. Liu, Sustainable Cities and Society 62, 102405 (2020)

14. J. He, Journal of Physics: Conference Series 1649(1), 012005 (2020)

15. G.E. Artamonov, V.V. Erofeeva, V.A. Gutnikov, S.L. Yablochnikov, 2020 International Conference on Engineering Management of Communication and Technology, EMCTECH 2020 - Proceedings 9261566 (2020)

16. V. Bukhtoyarov, S. Dorokhin, V. Ivannikov, A. Shvyriov, K. Yakovlev, IOP Conference Series: Materials Science and Engineering 918(1), 012060 (2020)

17. V.A. Ilyichev, V.I. Kolchunov, V.A. Gordon, N.V. Bakaeva, IOP Conference Series: Materials Science and Engineering 913(5), 052037 (2020)

18. D. Saadi, I. Schnell, E. Tirosh, X. Basagaña, K. Agay-Shay, Environmental Research 187, 109687 (2020)

19. N. Danilina, A. Majorzadehzahiri, IOP Conference Series: Materials Science and Engineering 869(2), 022027 (2020)

20. L. Filimonyuk, Y. Lobeyko, V. Ivashova, R. Chvalun, A. Kalashova, E3S Web of Conferences 203, 05021 (2020) 